\title{
First report of Cucumber mosaic virus on Canna indica in Iran
}

\author{
Abbas Saidi • Mehdi Safaeizadeh
}

Received: 14 December 2010 / Accepted: 4 June 2012 / Published online: 30 June 2012

(C) Australasian Plant Pathology Society Inc. 2012

\begin{abstract}
Cucumber mosaic virus (CMV) was detected in Canna indica by enzyme linked immonusorbent assay (ELISA) and reverse transcription polymerase chain reaction (RT-PCR) using CMV-specific primers. The Canna indica samples were collected from commercial horticultural greenhouses showing mosaic symptoms in the Varamin region in Tehran province of Iran. The virus infection was also confirmed on the basis of the symptoms on herbaceous indicator plants. To our knowledge, this is the first report of the natural occurrence of CMV on Canna indica in Iran.
\end{abstract}

\section{Keywords CMV $\cdot$ Canna indica $\cdot$ DAS-ELISA $\cdot$ RT-PCR Biological assay $\cdot$ Iran}

Canna indica L., an upright, perennial, rhizomatous herb species of the family Cannaceae, are widely cultivated in greenhouses as an ornamental flowering plant in the Varamin region of eastern Tehran province for export to other areas in the country. So far, five viruses have been reported to infect canna including; Bean yellow mosaic virus (BYMV; Castillo et al. 1956), Canna yellow mottle virus (CaYMV; Yamashita, et al. 1985), Canna yellow streak virus (CaYSV; Monger, et al. 2007), Cucumber mosaic virus (CMV; Lockhart 1988), and Tomato aspermy virus (TAV; Hollings and Stone 1971). Recently, Indian canna (C. indica) plants showing leaf mosaic symptoms were observed in greenhouses in Varamin. Because of the potential economical impacts, we investigated the symptomatic plants to determine the causal agent.

A. Saidi $(\bowtie) \cdot$ M. Safaeizadeh

Department of Biotechnology, Faculty of New Technologies and Energy Engineering, Shahid Beheshti University,

G.C.,

Tehran, Iran

e-mail: abbas.saidi@gmail.com
A survey of greenhouses and gardens in the Varamin region was conducted in spring 2010, collecting a total of 37 C. indica leaf samples showing mosaic and necrosis symptoms (Fig. 1a). Leaf extracts were tested by double-antibody sandwich enzyme-linked immunosorbent assay (DAS-ELISA) described by Clark and Adams (1977) for evaluation of Arabis mosaic virus (ArMV), CMV, Tomato bushy stunt virus (TBSV), Tomato ring spot virus (ToRSV), Tomato spotted wilt virus (TSWV), and Tomato yellow leaf curl virus (TYLCV), using polyclonal antibodies obtained from Bioreba, Switzerland. Samples were considered virus-positive when the optical density (OD) exceeded the mean plus three standard deviations of the OD of the healthy controls. Extracts from three of the samples $(8.1 \%)$ gave a positive reaction indicating presence of CMV. Except for the reaction to CMV none of the samples reacted with other antibodies mentioned above.

RT-PCR was used to verify CMV infection of the three positive samples (CMV-Vr 1, CMV-Vr 2 and CMV-Vr 3). Using TRI-Reagent (Sigma) total RNA was extracted from $70 \mathrm{mg}$ of symptomatic areas of the leaves according to the manufacturers' protocol and resuspended in $50 \mu$ d diethylpirocarbonate (DEPC)-treated $\mathrm{H}_{2} \mathrm{O}$. Healthy canna extracts collected from the same region were used as controls. RNA quality was determined by gel electrophoresis. Highly specific oligonucleotide primers (Blas et al. 1994) were used to amplify the conserved sequences of CMV RNA 3 (yielding 540 bp fragment).

The cDNAs were synthesized using RevertAid ${ }^{\mathrm{TM} M}$ MuLV Reverse transcriptase (M-MuLV, Fermentas, Germany) as per manufacturer's instructions. $2.5 \mu \mathrm{l}$ of the RT reaction was used for PCR and reaction mixture was performed as described by Samuitiene and Navalinskiene (2008) with minor modifications and optimization for use with Taq DNA polymerase (Fermentas, Germany), in a total volume of $25 \mu \mathrm{l}$ reaction. Thermal cycling consisted of an initial denaturation step of $95{ }^{\circ} \mathrm{C}$ for 5 min followed by 40 

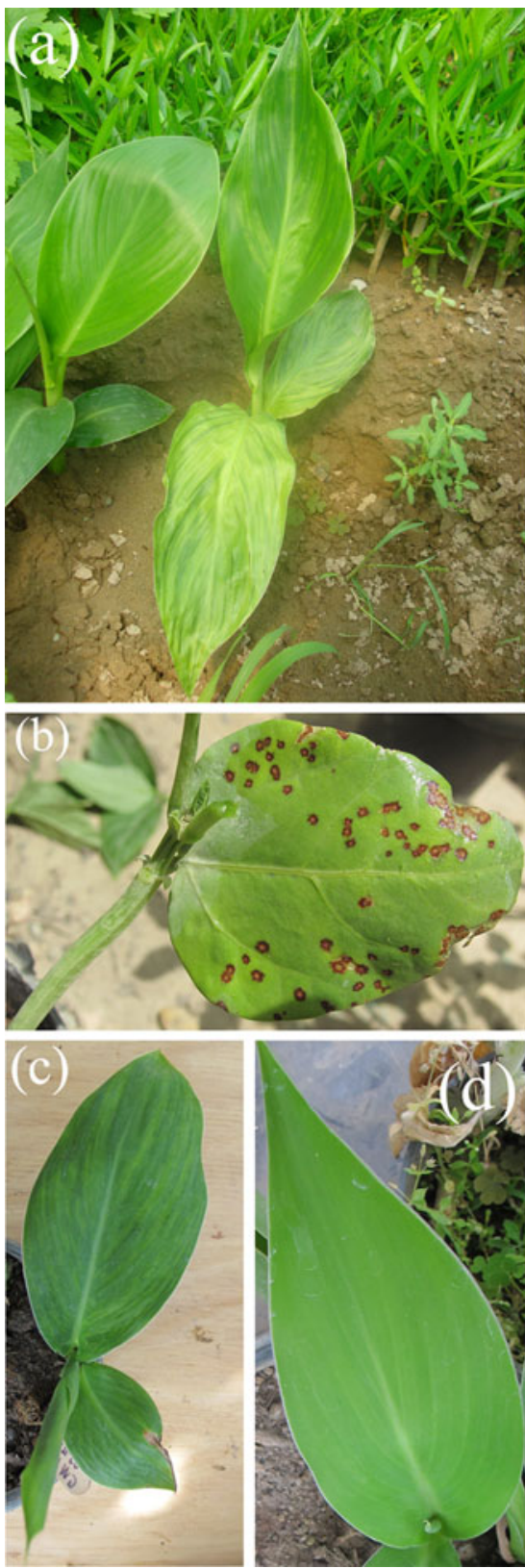

Fig. 1 a Mosaic symptom observed on a leaf of a Canna indica infected with CMV-Vr 2 plant collected in Varamin region. b chlorotic local lesion on Vigna unguiculata induced by CMV-Vr $1 ; 8$ days after mechanical inoculation. c Confirmation to CMV infection 40 days post inoculation for CMV-Vr 1. d uninoculated Canna indica which was negative to CMV in DAS-ELISA and RT-PCR

cycles of $95{ }^{\circ} \mathrm{C}$ for $60 \mathrm{~s}, 42^{\circ} \mathrm{C}$ for $60 \mathrm{~s}$ and $72{ }^{\circ} \mathrm{C}$ for $60 \mathrm{~s}$. A final step of $8 \mathrm{~min}$ at $72{ }^{\circ} \mathrm{C}$ ended the cycle. The PCR products were analyzed by electrophoresis in a $2 \%$ agarose gel. An amplicon of the expected size (540 bp) was observed in leaf samples of symptomatic (Fig. 2), but not in healthy plants collected from the same locations.

Mechanical inoculation tests were carried out using leaf sap of the three CMV positive samples by macerating in $0.1 \mathrm{M}$ potassium phosphate buffer, $\mathrm{pH} 7.2$ (supplemented

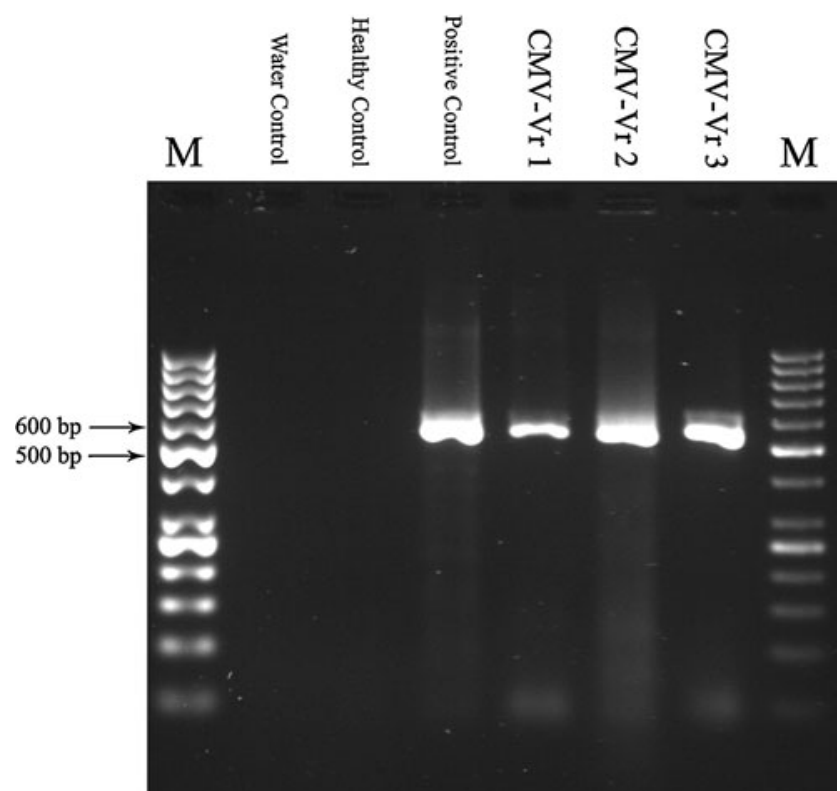

Fig. 2 Assay for specific detection of CMV infected Canna indica. Agarose gel of RT-PCR products from total RNA extracts prepared from canna plants. Line 1 and 8: molecular weight marker (50 bp, DNA ladder; Fermentas, Germany); Line 2: PCR reaction mix includes water instead of nucleic acid; Line 3: Healthy control (total RNA extract from healthy Canna indica which was negative in DASELISA to CMV and without any symptom to virus infection; Line 4: RT-PCR products from total RNA extracts prepared from tomato infected with CMV. Line 5 to 7: CMV-Vr 1, CMV-Vr 2 and CMV-Vr 3 , respectively. DNA bands were visualized and photographed with UV illuminator (Proxima 10 phi)

with $0.01 \mathrm{M}$ EDTA acid and $0.1 \%$ sodium sulfite), at a ratio of $1: 10(\mathrm{w} / \mathrm{v})$ and the extract rubbed on carborundum-dusted test plants. All of the isolates (CMV-Vr 1, CMV-Vr 2 and CMV-Vr 3) produced local lesions on Chenopodium amaranticolor, Chenopodium quinoa, and Vigna unguiculata, 8 12 days post-inoculation (Fig. 1b).

CMV-Vr 1, CMV-Vr 2 and CMV-Vr 3 were also successfully transmitted by mechanical inoculation to Nicotiana tabacum cv. Samsun and severe mosaic leaf malformation were observed three weeks post-inoculation. This confirms the symptoms previously reported for CMV (Kaper and Waterworth 1981) and infection of tobacco plants with CMV was confirmed by DAS-ELISA. Also, in order to confirm infection to $\mathrm{CMV}$, healthy young leaves of canna which were without any symptoms to virus infection and negative in DAS-ELISA to ArMV, CMV, TBSV, ToRSV, TSWV, and TYLCV were reinfected with an extract from inoculated Nicotiana tabacum cv. Samsun. Before inoculation, as the further confirmatory test, plants were re-checked by RT-PCR with CMV specific primers as mentioned above and all of them were negative in RT-PCR to CMV infection. The 40 days post inoculation mosaic symptoms were observed on infected canna leaves (Fig. 1c, for CMV-Vr 1) and infection to CMV was confirmed by DASELISA and RT-PCR. 
Based on the DAS-ELISA results, RT-PCR reaction, the development of leaf symptoms on tested plant species and, Koch's postulates confirmation; it is therefore, concluded that CMV is one of the causal agent that infecting canna in the studied area. Virus-like symptoms observed on other collected samples will require further studies to detect any other canna infecting viruses in the Varamin region. This is the first report of natural CMV infection of Canna indica in Iran.

Acknowledgements We are grateful to the Shahid Beheshti University research fund for support of this work. Special thanks are due to other colleague at the Department of Biotechnology for their valuable collaboration.

\section{References}

Blas CDe, Borja MJ, Saiz M, Romero J (1994) Broad spectrum detection of Cucumber mosaic virus (CMV) using the polymerase chain reaction. J Phytopathol 141:323-329
Castillo BS, Yarwood CE, Gold AH (1956) Canna-mosaic virus. Plant Disease Reporter 40:169-172

Clark MF, Adams AN (1977) Characteristics of the microplate method of enzyme-linked immunosorbent assay for the detection of plant viruses. J Gen Virol 34:475-483

Hollings M, Stone OM (1971) Tomato aspermy virus. CMI=AAB Descriptions of Plant Viruses No. 79, Wallingford

Kaper JM, Waterworth HE (1981) In: Kurstak E (ed) Handbook of plant virus infections and comparative diagnosis. Elsevier/NorthHolland Biomedical Press, Amsterdam, p 257

Lockhart BEL (1988) Occurrence of Canna yellow mottle virus in North America. Acta Horticulture 234:69-72

Monger WA, Harju V, Skelton A, Seal SE, Mumford RA (2007) Canna yellow streak virus: a new potyvirus associated with severe streaking symptoms in canna. Arch Virol 152:15271530

Samuitiene M, Navalinskiene M (2008) Occurrence of cucumber mosaic cucumovirus on ornamental plants in Lithuana. ZemdirbysteAgriculture 95(3):135-143

Yamashita S, Natsuaki T, Doi Y, Yora K (1985) Canna yellow mottle virus, a non-enveloped small bacilliformvirus in Canna sp. Ann Rev Phytopathol Soc Jpn 51:642-646 